\title{
Sustainable Soil Management in Ski Areas: Threats and Challenges
}

\author{
Emanuele Pintaldi ${ }^{1}$, Csilla Hudek ${ }^{1}$, Silvia Stanchi ${ }^{1,2}$ (D), Thomas Spiegelberger ${ }^{3}$ (1), \\ Enrico Rivella ${ }^{4}$ and Michele Freppaz ${ }^{1,2, *}$ \\ 1 Department of Agricultural, Forest and Food Sciences, University of Turin, Largo Paolo Braccini 2, 10095 \\ Grugliasco, Italy; emanuele.pintaldi@unito.it (E.P.); csilla.hudek@unito.it (C.H.); silvia.stanchi@unito.it (S.S.) \\ 2 NATRISK, Interdepartmental Research Centre on Natural Risks in Mountain and Hilly Environments, \\ University of Turin, Largo Paolo Braccini 2, 10095 Grugliasco, Italy \\ 3 National Research Institute of Science and Technology for Environment and Agriculture, \\ Research Unit Mountain Ecosystems, University Grenoble Alpes, 2 rue de la Papeterie, \\ F-38402 St-Martin-d'Hères, France; thomas.spiegelberger@irstea.fr \\ 4 Agenzia Regionale per la Protezione Ambientale-ARPA Piemonte, via Pio VII 9, 10135 Torino, Italy; \\ e.rivella@arpa.piemonte.it \\ * Correspondence: michele.freppaz@unito.it; Tel.: +39-011-670-8514
}

Received: 29 September 2017; Accepted: 16 November 2017; Published: 22 November 2017

\begin{abstract}
The skiing industry often represent the main contribution to mountain regions' economy, by providing several economic benefits and the improvement of services and infrastructure. Ski resorts also play a crucial role as an impacting factor, causing severe changes on Alpine landscape and ecosystems. In particular ski runs construction and operation have considerable impacts on alpine soils, influencing their chemical and physical properties which affecting the establishment and development of plant communities. The work provides a description of the changes in soil properties and the related effects on vegetation. It aims furthermore to investigate the recent best practices applied for a successful soil restoration after ski runs construction, which may contribute to a sustainable use of mountain soils and ecosystems. Based on the current regulatory framework, this review gives a global overview on how, in Europe and specifically in Italy, the sustainable use of soils is considered during the construction and management of ski runs. As the framework is still lacking of specific rules regarding soil protection and management on ski runs, the present work wishes to provide recommendations in order to fill this gap, favoring the effective application of best practices for soil protection during ski run construction and maintenance.
\end{abstract}

Keywords: soil erosion; artificial snow; soil restoration; ecosystem services

\section{Introduction}

Tourism on ski resorts brings many benefits to a mountain region, including economic diversification and the improvement of services and infrastructure [1]. However, as with many human activities, the development of winter sport resorts can impact the mountain landscape and environment [2,3]. The growing popularity of skiing has increased the demand for wide, smooth ski runs for their large capacity for skiing and easy slope preparation with the option of using artificial snow and snow grooming [4]. Construction and operation of ski runs, snowmaking facilities and lifts can have a large impact on mountain soils. Their construction involves many changes to the environment, such as the removal of the soil and vegetation cover as well as building roads. All these operations may induce geo-hazards such as soil erosion and interference with flora and fauna that can lead to the loss, deterioration or fragmentation of ecosystems [4,5]. In spite of these threats, ski resorts are found all around the world where environmental conditions allow. 
Ecological sustainability of land use requires maintaining essential soil functions, including biogeochemical cycling, water storage, nutrient cycling, and erosion control [6]. To effectively reduce the environmental impact of ski run construction and management, specific regulations need to be implemented along with effective, state-of-the-art best practices in order to ensure a successful soil restoration.

The present work contains specific sustainable soil management techniques that could successfully be applied and benefit many types of construction or land usage in high-elevation mountain sites. Some of the examples relate to civil engineering when long distance underground or aboveground linear infrastructures (e.g., high-voltage electric cables, pipelines, roads) are built on mountain slopes. In addition, water shortage is a pressing issue worldwide and storing water in reservoirs can be one helpful method to bridge dry periods. This work can offer best soil management techniques that could be implemented in the construction of water reservoirs made for artificial snowmaking as well as storing drinking water. Best soil management techniques applied in ski run construction could successfully mitigate the post-mining soil and site hazards such as erosion, the contamination of the on- and off-site environment and the aesthetic impact on landforms.

\section{Extension of Ski Areas}

\section{European Alps and Other Countries}

Over 2000 ski resorts attract 400 million visitors worldwide distributed in 100 different countries, 85 outdoor and 15 indoor or dry outdoor ski centers [7]. The Alps host $36 \%$ of the ski resorts and $84 \%$ of the major ski areas, and attracting $80 \%$ of total skiers [7]. This represents a major economic driver to the Alpine economy. There is approximately a total of $37,590.4 \mathrm{~km}$ of slopes and 15,808 ski lifts available in Europe, which reach a maximum elevation of $3899 \mathrm{~m}$ above sea level [8] and make up to $64.6 \%$ of the total kilometers of ski runs in the world. In the Alps alone, there are more than 10,000 ski lifts covering approximately $28,500 \mathrm{~km}$ of ski runs. As ski area size is one of the most valued criteria for the majority of skiers when selecting their ski destination, some ski areas tend to exaggerate their size. This has led to a new, independent and standardized measurement system with a Seal of Approval for resorts, which seeks to prove the genuine size of ski areas [7]. The density of ski slopes per massif on European Alps and on the Pyrenees can exceed 0.04 slopes $/ \mathrm{km}^{2}$ [9], revealing the high pressure exerted by ski activities on mountain territories. In the Swiss Alps alone, $220 \mathrm{~km}^{2}$ are directly affected by ski pistes [10].

Abegg et al. [11] reported that most of the ski areas in the Austrian, French, German, Italian and Swiss Alps could face problems of global warming in the future which could lead to a dramatic reduction in the number of naturally snow-reliable ski areas in the Alps [12]. Apart from the Alps, Asia \& Pacific have the third largest market share, closely following the American market. Eastern Europe \& Central Asia and Asia \& Pacific provide 34\% of the skiers worldwide at the moment, but it is estimated that, by 2020, worldwide skier visits may increase to over 420 million, if participation continues to grow steadily in China and in Eastern Europe countries [7,13].

Regarding Italy, a recent census conducted from 2009 to 2016 by INGAM (Ingegneria Ambiente Montagna) [14] revealed a total number of 500 ski resorts, of which 70 are abandoned or inactive. Concerning the distribution of the ski resorts, 350 are located in the Alps and 120 in the Appennines, totaling around 6000 kilometers of ski runs. The following regions have the greatest total length of ski runs in Italy: Trentino-Alto Adige $(2000 \mathrm{~km})$, Piemonte $(1500 \mathrm{~km})$, Lombardia $(800 \mathrm{~km})$, Valle d'Aosta $(700 \mathrm{~km})$ and Abruzzo $(250 \mathrm{~km})$. 


\section{Operational Activities in the Ski Area}

\subsection{Ski Run Construction}

Ski runs are considered for all intents and purposes tourist-sports infrastructures and they have to respect specific technical, structural and safety characteristics, which require strong modifications to the natural environment. Ski run construction and the infrastructure connected to it (e.g., ski lift, snowmaking plants, etc.) involve many operations such as deforestation, excavation, surface leveling, drainage works, etc., which inevitably cause damage to the alpine habitat. Generally there are two main operations carried out during ski run construction: surface clearing and surface grading. Surface clearing consists of the clearing of woody vegetation from slopes (tall shrubs and trees) to provide open spaces for skiers. During construction through machine-grading, the natural vegetation cover and the topsoil are removed, most boulders are re-arranged to form the ski run bed, and coarse materials from lower horizons are mixed with finer upper soil and replaced to form the top layer [15]. These operations are implemented in order to reduce the thickness of snow required for safe and pleasurable skiing and they are mainly carried out during the summer. Moreover, surface smoothing reduces the amount of artificial snow required.

In Europe, the treeline oscillates around $2000 \mathrm{~m}$ above sea level. Surface corrections below that limit mainly affect forest soils (Figure 1), while at higher elevations geomorphological features such as rock glaciers or patterned ground areas are disturbed, although the disturbance of soil properties and alpine vegetation also have to be considered (Figure 2). Machine-grading is a common practice at all elevations in the Alps and, in comparison to clearing is more damaging to multiple indicators of ecosystem functions [16]. The impact on soil properties observed in graded ski runs may be especially long-lasting in high-elevation ecosystems where soil development tends to be slower. Nevertheless, if best practices for soil management are carried out, the ski-runs can be successfully used for grazing during the summer months.

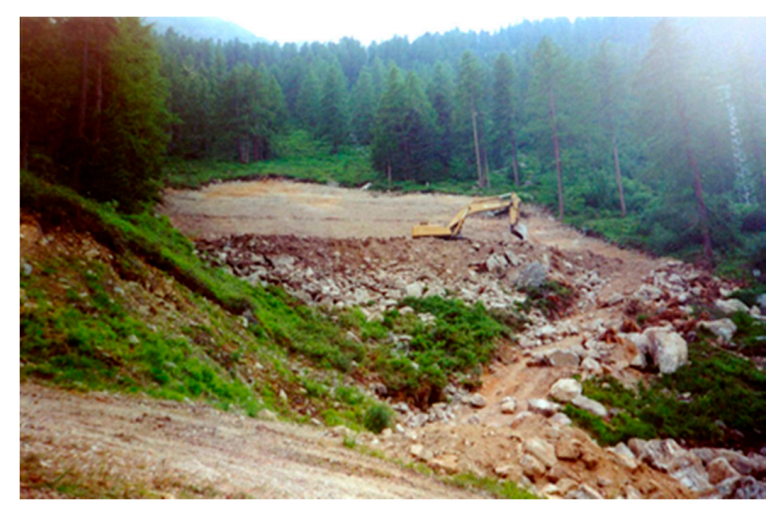

Figure 1. Ski-run construction below the treeline in the Italian Alps (Courtesy of Monterosa Ski Resort).

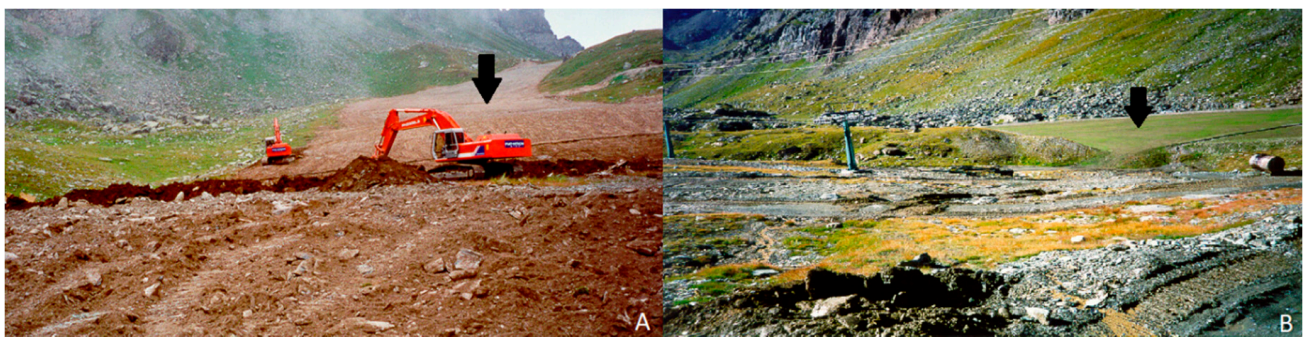

Figure 2. Ski run construction above the treeline in the Italian Alps (Courtesy of Monterosa Ski Resort). (A) The arrow indicates the ski run surface after the removal of rocks, levelling and the replacement of the topsoil; (B) The arrow indicates ski run surface 2 years after seeding. 


\subsection{Artificial Snow Making System Construction}

With the ongoing intensification of ski resorts, the use of artificial snow has spread, and the vegetation and soil properties have been influenced in an increasing area [17]. Snowmaking plants require a large amount of water $\left(\sim 220 \mathrm{~L} / \mathrm{m}^{2}\right)$, which is provided by rivers or artificial reservoirs. These constructions at high elevation can have a significant impact on soil properties and the environment. Reservoirs are built on flat areas, sometimes close to natural lakes or wetlands, with the potential to affect ecologically valuable and sensitive areas. The volume of reservoirs is large, reaching sometimes more than $100,000 \mathrm{~m}^{3}$.

The water (and often the compressed air) is distributed to the snow guns through pipelines, the construction of these pipelines at the edge of the ski runs may significantly affect areas where the soil is particularly prone to erosion (Figure 3).

In the perspective of climate change, the use of artificial snow is expected to increase considerably in the future. Snowmaking considered to be the most widespread adaptation strategy; able to extend the duration of the ski season, compensating for the decline in natural snow-reliability [11,18]. Abegg et al. [12] proposed the so-called "100-days rule" in Europe. This rule states that a ski area can only be operated successfully if a sufficient snow depth of $30 \mathrm{~cm}$ lasts for at least 100 days in 7 out of 10 seasons at the mean altitude of the ski area. In the Alps, this rule was found to be fulfilled above $1050 \mathrm{~m}$ in the Northern Alps, above $1200 \mathrm{~m}$ in the Central Alps and above $1500 \mathrm{~m}$ in the Southern Alps [11,19]. Currently, 91\% of 666 analyzed ski areas in the Alps can be considered snow reliable. This proportion would drop to $75 \%, 61 \%$ and $30 \%$ in a 1,2 and $4{ }^{\circ} \mathrm{C}$ warming scenario, respectively [12].

The reduction in ski season length due to climate change could be mitigated if artificial snowmaking is employed [19]. However, the economic limits of snowmaking are still poorly understood and potential increases in energy price and/or shortage of fossil fuels could affect the profitability of snowmaking [19]. This encourages new areas of research to be developed in order to better understand the winter tourism system.

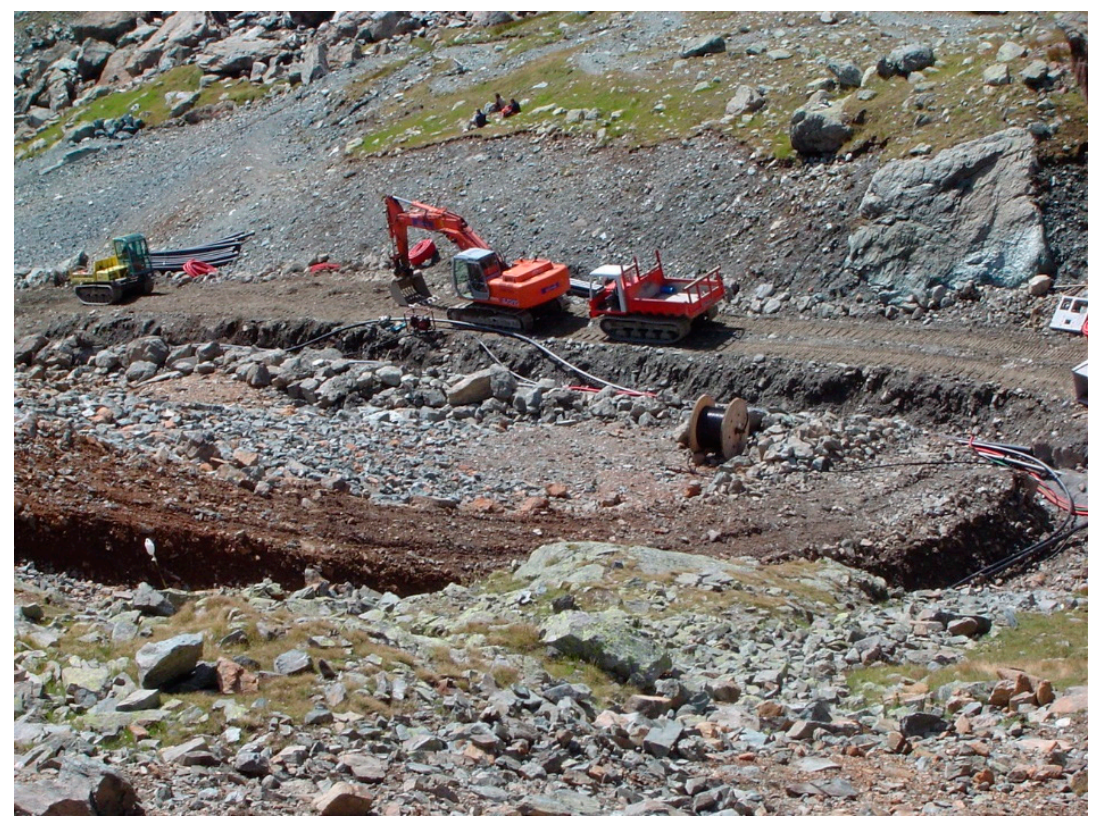

Figure 3. Construction of artificial snow-making system above the treeline in the Italian Alps (Courtesy Monterosa Ski Resort). 


\section{Effects of Ski Runs Construction on Soil Properties and Vegetation}

\subsection{Effects on Soil Physical and Chemical Properties}

The use of heavy machinery in the construction of ski slopes can significantly reshape the morphology of the landscape, with consequent impacts on soil properties. Barni et al. [15] reviewed the main techniques involved in land modelling and observed that in most cases, this involves bulldozing, with the removal of considerable soil to a depth of up to $1 \mathrm{~m}$. Freppaz et al. [4] remarked that such disturbance can be seen as an anthropogenic pedoturbation. As a consequence, deeper horizons or unweathered parent material are exposed to the atmosphere and consequently to weathering processes. Similar mechanical disturbances have been evidenced by Curtaz et al. [20] for agricultural soils subject to land reshaping, in a work that aimed at monitoring the recovery of soil properties after disturbance. Despite the study focussing on agricultural land, some general conclusions can be drawn that may also hold true for the soils of ski areas. The original soil thickness was reduced due to artificial truncation processes, losing the pre-existing soil horizonation, this resulting in the rebuilding of a deeply altered topsoil, within a poorly differentiated profile. This results in a decrease in physical soil quality, as evidenced by the degradation of soil structure and consistency. The newly built soil, similarly to terraced soils, can be regarded as the product of an anthropogenic "Entisolization process" [21] and can be particularly vulnerable to erosion processes. Despite a marked worsening of soil physical properties, a trend towards the restoration of the initial properties was observed [20]. Laboratory indicators such as soil aggregate stability and consistency could be therefore proposed to study the evolution of ski runs after soil disturbance.

Disturbances due to ski-run construction may also result in significant changes in particle-size distribution and content of organic carbon [4,20], again affecting the aggregate stability and porosity which are controlled by the soil organic matter as the main binding agent in alpine topsoils [22]. The altered physical soil properties due to machine grading, also results in an altered soil water content and can cause increased surface flow and lead to impact the water system of a catchment area [23]. In addition, nutrient imbalance can be observed, with potential effects on the plant community $[4,15]$. The potential vulnerability of mountain soils to erosion and degradation processes was assessed and mapped using a large number of indicators by Stanchi et al. [24], who proposed the use of a comprehensive soil vulnerability index including soil aggregation and aggregate stability (wet aggregate stability, clay aggregation index), consistency (Atterberg limits), drainage (Hydrologic group), and site conditions (slope, topography, vegetation). A similar approach could be adopted also in the specific case of ski runs, in order to monitor soil properties over time.

The specific effects of ski run construction on soil properties however, derives also from winter management. In fact, snow density changes due to grooming and the use of artificial snow during the ski season may also strongly influence the soil characteristics of ski slopes. Groomed snow increases snow density and reduces snow depth compared with ungroomed areas. Snow compaction reduces the insulation capacity of the snowpack and, consequently, the underlying soil can experience considerable freezing with subsequent effects on soil nutrient dynamics and plant development [17]. The gas permeability of the snowpack on ski pistes is strongly decreased by the formation of ice layers [25], hindering gas exchange between the snow surface and the snow base. Consequently, due to the respiration of soil microorganisms, the oxygen concentration at the soil surface can be decreased.

The use of artificial snow due to the greater snow mass on ski runs, can delay the beginning of the snow-free season by more than two weeks. The average amounts of nutrient salts and ions in the melting water are generally higher on pistes with artificial snow. Although this melting water is still of drinking-water quality, there is the possibility that the composition of soil and vegetation will be altered [17].

Given the large number of effects caused by ski run construction, it is clear how the alteration of the original soil properties can result in a change in the ecosystem services provided by mountain soils immediately after machine-grading. Some potential effects on ecosystem services following machine 
grading are presented in Table 1 based on expert judgment, literature review [26] and following Freppaz et al. [4].

Ski areas are managed almost exclusively for recreation, when they might also be managed to minimize negative impacts on compatible ecological services, such as water storage, nutrient cycling, and maintenance of biodiversity [16].

If appropriate soil restoration techniques were applied, the ski run could potentially be grazed with only a slight reduction in productivity in comparison to undisturbed areas. The recovery time of the previous conditions could be different. Delgado et al. [27] reported that after 14 years of grass seeding the values of some soil quality indicators were restored. However, even if the soil restoration was successful, the reduction of soil organic matter and the change in soil texture reduced the water holding capacity and increased the susceptibility to erosion processes. At the same time, the development of new anthropogenic soils may contribute to an increase in the pedodiversity of the area and differentiating new elements of the landscape while still supporting recreational activities.

Table 1. Ecosystem services (ESS) provided by soil and related changes (expert based) immediately after machine-graded ski run construction.

\begin{tabular}{|c|c|c|}
\hline ESS Category & ESS Class & Changes in Services \\
\hline \multirow{3}{*}{ Provisioning } & Agriculture biomass/Food production & Degraded \\
\hline & Forest biomass production & Degraded \\
\hline & Water storage for humans and plants & Degraded \\
\hline \multirow{4}{*}{ Regulating } & Water filtration, purification & Degraded \\
\hline & Climate regulation & Degraded \\
\hline & Degradation, detoxification and immobilization of pollutants & Degraded \\
\hline & Slope stability control & Degraded \\
\hline \multirow{2}{*}{ Supporting } & Habitat for soil organisms, gene pools and soil biodiversity preservation & Degraded \\
\hline & Nutrient storage, exchange, and circulation & Degraded \\
\hline \multirow{2}{*}{ Cultural } & Archive for cultural heritage, soil type as natural heritage & Stationary \\
\hline & Recreation and tourism & Improved \\
\hline
\end{tabular}

\subsection{Effects on Vegetation}

The environmental conditions at high-elevation areas require specialized plant species to colonize them. When conditions change (e.g., ski slope construction), specialized plants either fail to survive or are suppressed by other plants better suited for the new conditions. In cleared ski runs construction, the soil and seed bank remain undisturbed, which provides a valuable basis for the natural re-development of plant communities. When the soil surface is further manipulated to form a leveled ski run (machine-graded ski run), heavy machinery is often used to remove tree stumps and boulders. Furthermore, the top layer of soil, including the seed bank, is often removed or disturbed.

During construction, considerable changes take place in the soil's physical, chemical and biological properties [28]. This influences the establishment and development of plant communities which in return affects both the biotic and abiotic soil environment and the entire alpine ecosystem [15,28,29]. Therefore, restoration techniques have a crucial role to play in the success of damage mitigation and the rehabilitation of damaged ecosystems. As the disturbance in graded ski slopes is more severe than in cleared runs, it is more likely that graded sites will follow a primary vegetation succession during the restoration process [29], thereby prolonging the time needed for soil melioration and site rehabilitation.

Additionally, important factors from the winter season is the use of artificial snow making and snow grooming apparatus which is strongly linked and strongly affects the plant-soil interactions. The use of artificial snow involves the use of lake/river water or ground water, which has a different mineral composition and $\mathrm{pH}$ from natural snow. After snow melting, the excess water and the chemical composition of the melt water affects the physical quality of the soil and influences the soil's chemical composition. When biological additives are added to the process of artificial snow making there is 
a potential biological risk to the local plants and environment by the potential survival of pathogenic bacteria and/or related toxins [24]. An additional impact on the environment is when artificial snow hardeners are applied to solidify the surface of the snow. These chemicals would increase the nutrient availability and $\mathrm{pH}$ of the soil, providing advantages to plant species with higher nutrient demands which often outcompete other species, thus decreasing biodiversity [9]. Snow grooming can physically damage the vegetation under the snow cover, and hamper the recovery of the site. Pohl et al. [30] showed that compacted soil on ski slopes results in reduced rooting depth. Additionally, compacted sites have a significantly reduced infiltration rate which makes the soil and the site more susceptible to erosional processes. As mentioned above, compacted snow provides less insolation, resulting in lower soil temperatures during the winter which can cause physical and physiological stress to the plants. Warmer soil conditions would help the plants to save energy in cryoprotective measures [31]. On the other hand, Alpine vegetation stops respiring at around $-5{ }^{\circ} \mathrm{C}$ and $-10{ }^{\circ} \mathrm{C}$, which means plants do not expend metabolic energy. As a rule of thumb, early melting sites have richer soil than late melting sites [31]. In early melting sites, there are a greater number of species together with a higher rate of litter decomposition, humus content and microbial activity [28,31]. With excessively compacted snow cover, snow duration can be prolonged by an average of 2 weeks. This would lessen the vegetative period of plants, which reduces the abundance of early flowering plants and favours late species, shortening the period for seed propagation. The excess melting water has a cooling effect on the ground and provides conditions for more mesic species. Species diversity would help not only from a slope and soil stability point of view [32,33] but would also provide a greater diversity of plant compositions that can successfully survive and function under the effects of climate change.

\section{Best Practices for Soil Protection during Ski Run Construction and Management}

Restoration techniques have a crucial role to play in the success of damage mitigation and the rehabilitation of damaged ecosystems [2]. Barni et al. [14] and Rivella and Molinari [34] showed how the use of appropriate agronomic/pedologic techniques, conservation of the topsoil, selection of suitable plant material, and manuring after sowing have led to the establishment of a sufficiently dense plant cover, although it did not reach the percentage cover values of the adjacent natural alpine pasture.

Graded ski runs lose their seed bank, therefore the replenishment of seeds is a vital factor in the restoration process. There are various techniques used depending on site specifications, availability and cost-effectiveness; natural colonization or succession, use of commercial seed mixtures, site-specific seed mixtures and their combinations [35].

In the following section, we propose a best practice approach in three steps: (1) store and reuse original topsoil; (2) apply seed mixtures adapted to site conditions; and (3) manage the restoration site during summers in an appropriate manner.

\subsection{Topsoil Management on Ski Slopes}

More than 600 ha (mostly mountain and subalpine grasslands) are terraced and remodeled each year in the Northern French Alps [36]. For sites at higher altitudes, such disturbance can put the ecosystem back to the beginning of primary succession (parent materials outcrop) if an already existing soil layer is not handled in an appropriate way. More and more developers of skiing resorts and their contractors are cautious in the use of the superficial soil layer and store the living soil during the work period outside the construction area. While from an economic point of view, taking off and storing the living soil away from inertial material may represent higher costs, this method allows a quicker recovery of the vegetation due to a higher nutrient level compared to underlying soil layers, higher microbial biomass and activity, and a better representation of the soil seed bank. In the long term, snow holding capacity of the restored and well-vegetated site will be higher and snow more easily manageable, while other aspects such as scenic beauty and forage quantity may approach initial values more quickly (Figure 2A,B). Consequently, such approaches will increase social acceptance of 
the ski slope works, decrease the long-term restoration's initial and subsequent costs and increase of sustainable use of land and soil in ski areas. In addition to a careful handling of the living soil part, a rapid stabilization of the soil after the earth works will be more likely with appropriate revegetation.

\subsection{Application of Seed Mixtures}

Achieving a vegetation cover of at least $75 \%$ within the first two vegetation periods should be the aim of all restoration projects on ski slopes [37]. After the remodeling ski runs or other works linked to infrastructures of ski areas (access roads, infrastructures around lifts, network of channels for artificial snow making, etc.) and despite careful handling of the upper soil level, the soil seed bank, which is an essential factor in the restoration process, is often depleted. Various revegetation techniques exist and are used depending on site specifications, availability and cost-effectiveness to overcome this lack: natural colonization (succession), use of commercial seed mixtures containing mainly seeds multiplied during years in lowland regions, site-specific seed mixtures collected from local plant communities and combinations of all above [35].

Succession based on natural transportation of propagules of nearby species is the slowest process of all mentioned above and must be accompanied by other erosion control measures such as fixing jute nets to the ground.

While the necessity of revegetation is commonly accepted, in a majority of restoration projects commercial seed mixtures containing mainly tall, fast-growing grass are still used, due to their low costs. However, at high elevations, many abiotic factors such as temperature, precipitation, and exposure act as ecological filters, which constrain plant life. Several species of conventional seed mixtures do not tolerate such conditions and either do not germinate, suffer during the seedling stage or survive only during the first growing seasons. Consequently, the use of such non-adapted seed mixtures does not in many cases, achieve a sufficient vegetation cover to stop or significantly impede erosion, even with fertilizer application. In combination with steep slopes on ski runs and frequent intense rainfall events this leads to increased runoff and subsequent soil erosion. Moreover, commercial seed mixtures currently used usually contain fewer [4,12] species, mainly grasses (up to $99 \%$ of seeds) and legumes $[15,38]$. These species are hardly adapted to ski slopes and can have competitive advantages over native species during the first years, which can delay or inhibit the establishment of native vegetation and the related biodiversity. Soil quality can subsequently be altered as the decomposition of litter dominated by grasses can take twice as long compared to forb-dominated plant communities which influences the nutrient discharge of the soil [28].

A long-lasting vegetation cover and a reduction of surface erosion seem much more achievable with local seeds adapted to areas where ski slope development occurs [35], than adding conventional seeds may even delay successful alpine natural vegetation recovery [39]. The use of site-specific seed mixtures can provide a great number of advantages both from an ecological and site management point of view. Site-specific seed mixtures require fewer nutrients and a lower amount of seeds compared to commercial seed mixtures. They provide lower amounts of biomass but produce a higher quality of biomass and become self-sufficient, natural grassland in a shorter period of time [35]. Higher species diversity compared to commercial seed mixtures also increases slope and soil stability $[32,33]$ and provide a more diverse plant composition that can successfully survive and function under the effects of climate change.

For about 20 years the use of local seeds has been tested on ski slopes in the eastern Alps, with clear results indicating a competitive advantage of local seeds over seed mixtures containing mainly lowland seeds [40]. Similar results are also reported from the Pyrenees [41]. First results are similar, underlining the importance of local species in the Eastern Alps [36]. New projects on this topic are ongoing [42]. 


\subsection{Appropriated Management of Restored Sites during Summer}

Summer slope management is also a vital component of a sustainable slope restoration process. This should involve the regular cutting back of the vegetation by hand or through grazing with special attention paid to preventing overgrazing. When necessary, reseeding should be applied in order to prevent erosion processes and the segmentation of the site. Therefore, the success of the restoration, particularly at high elevation sites, requires constant and accurate maintenance, as well as several years of monitoring [43]. The time factor, which implies constant and prolonged monitoring and maintenance, is crucial for the success of restoration process. Barni et al. [15] showed the establishment of a sufficiently dense plant cover in 10-12 years, though it did not reach the cover values of the adjacent natural alpine pasture. It is therefore unlikely that the ecosystem can recover enough in the immediate future to provide functions and services. However, with an appropriate restoration strategy, the system could at least be returned to provisioning and sustaining livelihoods, while also providing a significant increase in other ecosystem services.

\subsection{Challenges and Perspectives}

The creation of specific best practices guidelines (eventually implemented in the regulatory framework), represent a difficult challenge, given the high environmental variability and site-specific conditions of each ski resort. In addition, usually these practices come at great economic cost to ski operators, who are not encouraged to adopt them. However, an example comes from the National Ski Area Association [44], which created the Sustainable Slopes Program, adopted by the ski industry in 2000. This program provides ski areas with an overarching framework for sustainability and enhanced environmental performance. The program is based on the Environmental Charter, which contains 21 Environmental Principles that enable ski area operators to make sustainable use of natural resources. It is interesting to note that these principles are voluntary and provide overall guidance for ski areas in achieving good environmental stewardship [45], therefore, by adopting them, resorts have committed to go beyond regulatory compliance in those areas where improvements make environmental sense and are economically feasible. This produces many incentives, including reduced environmental impact, increased monetary savings, reduced regulatory liability, and increased positive public image. The ski resort operators are therefore encouraged in the application of these principles, because of the concept that good environmental practices are good business practices, and are expected by resort customers [46]. However as suggested by Rivera et al. [47] caution is advised as a voluntary program may not necessarily be effective in promoting complete environmental protection.

Although the Environmental Charter does not contain specific references to soil, the Sustainable Slopes Program represents an important model of how to combine the economic interests of the ski industry with a sustainable use of mountain ecosystems.

\section{Current Regulatory Framework for Soil Management on Ski Runs in the European Alps}

The regulatory framework of ski runs in the European Alps is rather complex. In particular, a general overview about the current national legislation reveals the lack of specific rules about the soil management on ski runs. Regarding the territory of the Alpine Convention (Table 2), the first document in which ski runs and related structure are mentioned is the Tourism Protocol of the Alpine Convention. Though no specific indication about soil management and protection are reported, the protocol provides important indications concerning the inclusion of ski lifts and ski runs in the environment. It reports that the development, maintenance and use of ski slopes should blend into the natural surroundings as much as possible, taking account of natural balances and biotope sensitivity. In addition, when natural conditions allow, developed areas should be replanted, giving priority to plant species native to the area. In the framework of the Alpine Convention, the Soil Conservation Protocol mainly considers the soil protection on ski runs, although in a general view. In particular, the Protocol takes into consideration the interaction of ski run construction with 
the protective function of forests and the soil restoration of disused areas. It also encourages the investigation of the potential effects of snow additives on soil properties.

In Italy, the regulatory framework appears very complex (Table 2), as besides national government, regions and provinces can issue their own specific rules on ski run management, though most of the current legislation is mostly oriented towards safety, not environmental aspects. For instance, only a few vague prescriptions are given about soil management during ski run construction and maintenance. However, currently, in order to guarantee the safeguarding of the environment, both the new construction and the extension of a ski run, is subjected to a preliminary and mandatory procedure, which targets the preliminary evaluations of the environmental effects. The Environmental Impact Assessment (EIA) is a technical and administrative procedure which gives an overall judgment about the compatibility between infrastructural works and the environmental effects (e.g., modifications, transformations and resources utilization) they bring about. This procedure, at European level, was introduced by the European Union directive 85/337/CEE and it was implemented in the respective national legislations. In Italy, the EIA is regulated by the legislative decree 3 May 2006 n. 152. However, for ski runs, each region (and province) has the authority to legislate within its territory.

Regarding soil management and protection, in the framework of ski runs, the EIA at regional level provides the evaluation of the effects deriving from the construction and the operation of ski lifts, ski run and artificial snow plants with specific size thresholds. However, no mandatory dispositions concerning soil investigations are reported. For instance, as suggested by Cernusca and Tappeiner [48], the procedure for the evaluation of impact should consider several soil parameters (e.g., horizon thickness, roots presence, $\mathrm{pH}$ ), in order to produce a detailed pedological appraisal of the current state and of the effects produced by the works. If the procedure reveals the occurrence of negative impacts despite mitigation measures, (e.g., revegetation, buffer strips, ecological corridors) the compensatory measures, (e.g., reforestation, wetlands construction, environmental recovery) are required. In order to evaluate the consistency of such measures the impact on and reduction of ecosystem services provided by soil due to this change in land use should be evaluated.

When the project affects an area which belongs to EU-Natura 2000 network, it is than subject to a further legislative process, the Incidence Assessment (VI) which aims to verify the potential negative effects of the project, considering the conservation targets of the protected area. As for the EIA, the VI is regulated both at national and regional level, though it does not contain specific and mandatory directives for soil management and protection except when the soil is considered a crucial component for the conservation of the habitat. In this case, soil investigations as well as mitigation or/and compensatory measures become mandatory.

Based on the previous considerations, it is clear how in Italy, the current regulatory framework on soils of ski runs is strongly oriented towards the preliminary evaluation of environmental impact. While no specific and mandatory dispositions are yet present (although existing in the form of technical manuals, e.g., Rivella and Molinari) [34], the management and protection of soil during ski run construction and maintenance, requires the creation of specific rules and their implementation in the current legislation. 
Table 2. Overview of the current legislation on soil protection in the ski areas.

\begin{tabular}{|c|c|c|c|c|}
\hline Country & Regional/National Sphere & Legislative Reference & General Content & Content Referred to Soil Protection \\
\hline $\begin{array}{l}\text { Europe-Alpine } \\
\text { Convention } \\
\text { geographic area }\end{array}$ & Alpine Convention countries & $\begin{array}{c}\text { Tourism Protocol } \\
\text { (Alpine Convention) } \\
\text { European law, } \\
\text { 22 December 2005, n. 337/43 }\end{array}$ & $\begin{array}{l}\text { To implement the obligations in } \\
\text { the field of tourism entered into } \\
\text { by the Contracting Parties to the } \\
\text { Alpine Convention. }\end{array}$ & $\begin{array}{l}\text { General disposition concerning the inclusion of } \\
\text { ski lifts and ski runs on ecosystems and } \\
\text { landscape (soil related) }\end{array}$ \\
\hline $\begin{array}{l}\text { Europe-Alpine } \\
\text { Convention } \\
\text { geographic area }\end{array}$ & Alpine Convention countries & $\begin{array}{l}\text { Soil Conservation Protocol } \\
\text { (Alpine Convention), } \\
\text { European law, } \\
22 \text { December 2005, n. 337/29 }\end{array}$ & $\begin{array}{l}\text { To implement the obligations in } \\
\text { the field of soil conservation } \\
\text { entered into by the Contracting } \\
\text { Parties to the } \\
\text { Alpine Convention. }\end{array}$ & $\begin{array}{l}\text { Where natural conditions allow it, disused or } \\
\text { impaired soils of ski runs shall be restored to } \\
\text { their original state or shall be recultivated. } \\
\text { Permits for the construction and levelling of ski } \\
\text { runs in forests with a protective function are } \\
\text { granted only in exceptional cases and with the } \\
\text { proviso that compensatory action is taken, } \\
\text { and that such permits are not granted for } \\
\text { fragile areas. } \\
\text { Chemical and biological additives for the } \\
\text { grooming of ski runs are permissible only if } \\
\text { proof of their ecological harmlessness has } \\
\text { been furnished. }\end{array}$ \\
\hline Italy & National & $\begin{array}{c}\text { National Law, } \\
24 \text { December 2003, n. } 363\end{array}$ & Rules for safety of winter sports & No specific disposition on soil management. \\
\hline Italy & National/Regional/Province & $\begin{array}{l}\text { Legislative Decree } \\
3 \text { May } 2006 \mathrm{n} .152 \text { and } \\
\text { following integrations; } \\
\text { regional and provinces laws }\end{array}$ & $\begin{array}{l}\text { Environmental Impact } \\
\text { Assessment (required for ski } \\
\text { run extension and new } \\
\text { construction at regional and } \\
\text { provincial level). }\end{array}$ & Evaluation of the effects on soil properties. \\
\hline Italy & National/Regional/Province & $\begin{array}{l}\text { Decree of the President of the } \\
\text { Republic, } 12 \text { March 2003, } \\
\text { n. 120; regional laws }\end{array}$ & $\begin{array}{l}\text { Incidence Assessment (required } \\
\text { for projects on Rete Natura } \\
2000 \text { habitats). }\end{array}$ & $\begin{array}{l}\text { Evaluation of the effects on soil properties } \\
\text { (mandatory when required) }\end{array}$ \\
\hline
\end{tabular}


Table 2. Cont

\begin{tabular}{|c|c|c|c|c|}
\hline Country & Regional/National Sphere & Legislative Reference & General Content & Content Referred to Soil Protection \\
\hline Italy & $\begin{array}{l}\text { Regione Autonoma } \\
\text { Valle d'Aosta }\end{array}$ & $\begin{array}{l}\text { Regional law } \\
17 \text { March } 1992 \mathrm{n} .9 \text { and } \\
\text { following integrations }\end{array}$ & $\begin{array}{l}\text { General rules about ski runs } \\
\text { (safety and } \\
\text { environmental aspects). }\end{array}$ & No specific disposition on soil management. \\
\hline Italy & Regione Piemonte & $\begin{array}{l}\text { Regional law } 26 \text { January } 2009, \\
\text { n. 2; modified by Regional } \\
\text { law } 7 \text { February 2017, n. } 1 .\end{array}$ & $\begin{array}{l}\text { Rules for the safety of winter } \\
\text { and summer sports in } \\
\text { mountain areas. }\end{array}$ & $\begin{array}{l}\text { Guarantee the safeguard of environment and } \\
\text { landscape and the reduction of soil consumption. } \\
\text { The managers must maintain annually ski run in } \\
\text { order to preserve slopes from soil erosion. }\end{array}$ \\
\hline Italy & Regione Lombardia & $\begin{array}{c}\text { Regional law } \\
1 \text { October 2014, n. } 26\end{array}$ & $\begin{array}{l}\text { Rules for promotion and } \\
\text { development of sport activities, } \\
\text { sport facilities and sport } \\
\text { professions in mountain. }\end{array}$ & No specific disposition on soil management. \\
\hline Italy & Provincia Autonoma di Trento & $\begin{array}{l}\text { Decree of the President of the } \\
\text { Provincial Council, } \\
\text { 22 September 1987, } \\
\text { n. 11-51/Legisl. }\end{array}$ & $\begin{array}{l}\text { Regulation of cableways and } \\
\text { ski runs. }\end{array}$ & $\begin{array}{l}\text { During the snow-free period undertake soil } \\
\text { arrangement in order to avoid soil erosion. } \\
\text { Guarantee permanent vegetation cover and the } \\
\text { efficiency of drainage systems. }\end{array}$ \\
\hline Italy & $\begin{array}{l}\text { Provincia Autonoma } \\
\text { di Bolzano }\end{array}$ & $\begin{array}{c}\text { Provincial law, } \\
23 \text { November 2010, n. } 14 \\
\text { modified by Provincial law } \\
13 \text { March 2013, n. } 1\end{array}$ & $\begin{array}{l}\text { Regulation of equipped ski } \\
\text { areas (safety for users, } \\
\text { management of ski runs to } \\
\text { guarantee safety). }\end{array}$ & No specific disposition on soil management. \\
\hline Italy & Regione Veneto & $\begin{array}{c}\text { Regional law, } \\
2 \text { November 2008, n. } 21\end{array}$ & $\begin{array}{l}\text { Regulation of cableways, ski } \\
\text { runs, artificial snow systems } \\
\text { and safety of winter sports. }\end{array}$ & $\begin{array}{l}\text { During the snow free period make soil } \\
\text { arrangement in order to preserve stability } \\
\text { avoiding soil erosion and the degradation of } \\
\text { land surfaces. Guarantee permanent vegetation } \\
\text { cover and the efficiency of drainage systems. }\end{array}$ \\
\hline Italy & Regione Friuli Venezia Giulia & $\begin{array}{l}\text { Regional law, } 24 \text { March } 1981 \\
\text { n. } 15 \text { modified by: Regional } \\
\text { law, } 8 \text { July 1991, n. } 26\end{array}$ & $\begin{array}{l}\text { Regulation of cableways and } \\
\text { ski runs }\end{array}$ & No specific disposition on soil management. \\
\hline
\end{tabular}


Regarding the regulation framework of other European countries, the situation again seems to be unclear. To the best of our knowledge no specific rules for soil management and protection on ski runs can be found, although EIA procedure is mandatory in other member states. In France for example, current law governs the development, creation or modification of ski runs, which must comply with the requirements of a territorial coherence plan or a local urbanism plan as with other constructions (roads, building), though there is no specific mention of soil. In addition, depending on the nature (ski lifts, ski runs, snow making installations, snow making lake) and the extent of the project (higher or lower than 2 ha), an environmental impact assessment may be required. However, despite the lack of specific regulation, the operators have, to a large extent, integrated revegetation into their ski slopes management practice to reduce the risk of erosion and limit the impact on the landscape. It is a voluntary process widely adopted by operators after awareness-raising efforts for several years. Based on these considerations, it is quite clear that soil management on ski runs depends mostly on the will of operators, therefore the adoption of specific legislation in the other countries would be desirable.

Currently, as in Italy, the EIA procedure in the other member states seems to be the only instrument which considers soil conservation during ski run construction, although in the framework of preliminary evaluation of the environmental impact. In Austria the EIA procedure is required when a new area is used for new slopes or new ski lifts in glacial skiing areas or when the opening of areas to join existing slopes with lifts or build new slopes affecting an area of more than 20 hectares. Therefore, the EIA procedure represents an important instrument in the evaluation of environmental impact, although it is lacking in specific and mandatory regulations on the evaluation method of the impact on soil. These preliminary assessment studies, are typically supported by analyses conducted over broad areas on a small scale, based on limited field surveys and extensive use of Geographical Information System (GIS) indicators [49], therefore specific and technical rules on soil management on ski runs would be necessary.

\section{Discussion}

The lack of specific dispositions on soil protection and management during ski run construction and maintenance represents a difficult challenge for the sustainable use of mountain resources. In Italy, this could be addressed through the implementation in the regulatory framework of the best practices in the form of guidelines to be followed by operators during ski run construction and management. In general, best practice guidelines are already available but their application is not mandatory by law, which remains vague and does not give detailed operational protocols for soil protection on ski runs.

The first goal therefore should be the creation of guidelines, based on the current existing best practices, eventually through the involvement of competent authorities (e.g., in Italy Agenzia Regionale per la Protezione Ambientale (ARPA) and Istituto Superiore per la Protezione e la Ricerca Ambientale (ISPRA)). Some guidelines for soil protection and management, which represent the only technical regulations for operators, already exist [50-52], but they are not specifically made for soils on ski runs and therefore may not be directly applicable. Considering the high vulnerability of mountain soils [53] and their potential to generate significant diversity and a magnitude of ecosystem services [26], the guidelines must be "tailored" considering the uniqueness of the mountain pedo-environment.

The creation of guidelines for soil management on ski runs implies some issues, because of the high environmental variability and the site-specific conditions of each ski resort. However, they can represent the basic rules which can be applied in specific cases perhaps through the support of research activities. As well as the creation of these guidelines, another challenge is represented by the implementation in the regulatory framework, which can make the application of the best practices mandatory. The Tourism and the Soil Conservation Protocol in the Alpine Convention, surely represents a good starting point. They have introduced concepts related to restoration techniques, such as the use of native species for revegetation though only on disused 
or impaired soils of ski runs and does not include regulations about the continual maintenance of soils, nor rules on the controls needed to achieve a successful restoration.

Another option could be the modification and adoption, at European and national level, of an already existing program such as the Sustainable Slopes. It is a program specifically designed for ski resorts and actively and directly involved ski operators. They are also encouraged to voluntarily apply best practices for soil management in the ski areas. This is with the goal of ensuring the best conditions for winter sports as well as sustainable tourism that is increasingly sensitive and aware of environmental issues.

\section{Conclusions}

The construction and management of ski runs has serious effects on mountain soils, leading to the significant modification of their physical and chemical properties, which in turn negatively affect the mountain ecosystems and the ecosystem services they provide. The application of best practices for soil management could quicken the recovery of the soil ecosystem services and contribute to the sustainable use of mountain soils. Although examples of best practices already exist, they are not yet collected as specific guidelines and not implemented in the Italian regulatory framework. Therefore the lack of specific and mandatory rules for soil protection and management during ski run construction and maintenance represents an important gap in the pursuit of the objectives of sustainable use of mountain soils and ecosystems. The modification and adoption of a ski-related program such as Sustainable Slopes could be a model to achieve these objectives.

Application of best practices during ski run construction and management should be mandatory for all ski area developers in order to mitigate damage and quicken the recovery of these degraded environments. There is a need for long-term ecological monitoring to provide answers to various soil management issues related to ski run construction. This could open up new areas of research on soil restoration in ski areas, with potential benefits to sustainable soil management in mountain areas.

Acknowledgments: This work was co-financed by the European Regional Development Fund in Interreg Alpine Space project Links4Soils (ASP399): Caring for Soil-Where Our Roots Grow. (http://www.alpinespace.eu/projects/links4soils/en/the-project). TS acknowledges part funding by the FEDER/FNADT project "Sem'les Alpes". Many thanks to Monterosa Ski Resort (project stakeholder) for providing data and logistical support.

Author Contributions: Emanuele Pintaldi wrote the manuscript, collected and analyzing the data about regulatory framework; Csilla Hudek contributed to the editing of the manuscript, provide the chapters about Effects on Vegetation and contributed to the chapter Best practices; Silvia Stanchi contributed to the editing of the manuscript and provide the chapter Effects on soil properties; Thomas Spiegelberger contributed to write the chapter Best practices; Enrico Rivella provided guidance about regulatory framework; Michele Freppaz conceived and designed the paper and contributed to wrote each sections. All authors have read and approved the final manuscript.

Conflicts of Interest: The authors declare no conflict of interest.

\section{References}

1. Lasanta, T.; Laguna Marín-Yaseli, M.; Vicente-Serrano, S.M. Do tourism-based ski resorts contribute to the homogeneous development of the Mediterranean mountains? A case study in the Central Spanish Pyrenees? Tour. Manag. 2007, 28, 1326-1339. [CrossRef]

2. Freppaz, M.; Filippa, G.; Caimi, A.; Zanini, E. Sustainable tourism in Northwestern Alps: Winter sports impact on pasture lands. In Yearbook of the "Gh Zanc" Institute of Economic Researches; Gheorghe Zane Institute for Economic and Social Research: Iași, Romania, 2010; Volume 19, pp. 79-93.

3. De Jong, C. Environmental impacts of winter sport resorts: Where do we go from now? In Proceedings of the 1st Workshop on the Future of Winter Tourism (FWT2017), Rovaniemi, Finland, 3-5 April 2017; pp. 86-106.

4. Freppaz, M.; Filippa, G.; Corti, G.; Cocco, S.; Williams, M.W.; Zanini, E. Soil Properties on Ski-Runs. In The Impacts of Skiing and Related Winter Recreational Activities on Mountain Environments; Rixen, C., Rolando, A., Eds.; Bentham Science Publisher: Bussum, The Netherlands, 2013; pp. 45-64. 
5. David, G.C.L.; Bledsoe, B.P.; Merritt, D.M.; Wohl, E. The impacts of ski slope development on stream channel morphology in the White River National Forest, Colorado, USA. Geomorphology 2009, 103, 375-388. [CrossRef]

6. Sanchez-Maranon, M.; Soriano, M.; Delgado, G.; Delgado, R. Soil quality in Mediterranean mountain environments, effects of land use. Soil Sci. Soc. Am. J. 2002, 66, 948-958. [CrossRef]

7. Vanat, L. 2017 International Report on Snow \& Mountain Tourism-Overview of the Key Industry Figures for Ski Resorts, 9th Edition, Geneva, Switzerland, 2017. Available online: http:/ / www.vanat.ch/RM-worldreport-2017-vanat.pdf (accessed on 15 June 2017).

8. Skiresort. Available online: http://www.skiresort.info/ski-resorts/europe/ (accessed on 11 September 2017).

9. Nordregio. Mountain Areas in Europe: Analysis of Mountain Areas in EU Member States, Acceding and Other European Countries; Nordic Center for Spatial Development-Nordregio: Stockholm, Sweden, 2004; p. 271, ISBN 91-89332-35-0.

10. Roux-Fouillet, P.; Wipf, S.; Rixen, C. Long-term impacts of ski piste management on alpine vegetation and soils. J Appl. Ecol. 2011, 48, 906-915. [CrossRef]

11. Abegg, B.; Bürki, R.; Elsasser, H. Climate change and tourism in the Alps. In Managing Alpine Future; Borsdorf, A., Stötter, J., Veulliet, E., Eds.; VÖAW: Wien, Austria, 2008; pp. 73-80.

12. Abegg, B.; Agrawala, S.; Crick, F.; de Montfalcon, A. Climate change impacts and adaptation in winter tourism. In Climate Change in the European Alps; Agrawala, S., Ed.; OECD Publishing: Paris, France, 2007; pp. 25-60.

13. Mapsofworld. Available online: https://www.mapsofworld.com/world-ski-resorts.ht (accessed on 29 August 2017).

14. INGAM. Ingegneria Ambiente Montagna. Available online: www.ingam.com (accessed on 29 August 2017).

15. Barni, E.; Freppaz, M.; Siniscalco, C. Interactions between Vegetation, Roots, and Soil Stability in Restored High-altitude Ski Runs in the Alps. Arct. Antarct. Alp. Res. 2007, 39, 25-33. [CrossRef]

16. Burt, J.W.; Rice, K.J. Not all ski slopes are created equal: Disturbance intensity affects ecosystem properties. Ecol. Appl. 2009, 19, 2242-2253. [CrossRef] [PubMed]

17. Rixen, C.; Freppaz, M. Winter sports: The influence of ski piste construction and management on soil and plant characteristics. In Understanding Mountain Soils: A Contribution from Mountain Areas to the International Year of Soils 2015; Romeo, R., Vita, A., Manuelli, S., Zanini, E., Freppaz, M., Stanchi, S., Eds.; FAO: Rome, Italy, 2015; pp. 81-82, ISBN 978-92-5-108804-3.

18. Gobiet, A.; Kotlarski, S.; Beniston, M.; Heinrich, G.; Rajczak, J.; Stoffel, M. 21st century climate change in the European Alps-A review. Sci. Total Environ. 2014, 493, 1138-1151. [CrossRef] [PubMed]

19. Steiger, R. The impact of climate change on ski season length and snowmaking requirements in Tyrol, Austria. Clim. Res. 2010, 43, 251-262. [CrossRef]

20. Curtaz, F.; Stanchi, S.; D’Amico, M.E.; Filippa, G.; Zanini, E.; Freppaz, M. Soil evolution after land-reshaping in mountains areas (Aosta Valley, NW Italy). Agric. Ecosyst. Environ. 2014, 199, 238-248. [CrossRef]

21. Dazzi, C. L'erosione "genetica" dell'ecosistema suolo. In Proceedings of the SISS Conference Il Ruolo della Pedologia Nella Pianificazione e Gestione del Territorio, Cagliari, Italy, 6 June 1995; pp. 197-202.

22. Stanchi, S.; Freppaz, M.; Zanini, E. The influence of Alpine soil properties on shallow movement hazards, investigated through factor analysis. Nat. Hazards Earth Syst. Sci. 2012, 12, 1845-1854. [CrossRef]

23. Pintar, M.; Mali, B.; Kraigher, H. The impact of ski slopes management on Krvavec ski resort (Slovenia) on hydrological functions of soils. Biologia 2009, 64, 639-642. [CrossRef]

24. Stanchi, S.; Freppaz, M.; Godone, D.; Zanini, E. Assessing the susceptibility of alpine soils to erosion using soil physical and site indicators. Soil Use Manag. 2013, 29, 586-596. [CrossRef]

25. Rixen, C.; Stoeckli, V.; Ammann, W. Does artificial snow production affect soil and vegetation of ski pistes? A review. Perspect. Plant Ecol. Evol. Syst. 2003, 5, 219-230. [CrossRef]

26. Vargas, R.; Castro, A.; Ziadat, F. Mountain soils and ecosystem services. In Understanding Mountain Soils: A Contribution from Mountain Areas to the International Year of Soils 2015; Romeo, R., Vita, A., Manuelli, S., Zanini, E., Freppaz, M., Stanchi, S., Eds.; FAO: Rome, Italy, 2015; pp. 8-9, ISBN 978-92-5-108804-3.

27. Delgado, R.; Sanchez-Maranon, M.; Martin-Garcia, J.M.; Aranda, V.; Serrano-Bernardo, F.; Rosua, J.L. Impact of ski pistes on soil properties, a case study from a mountainous area in the Mediterranean region. Soil Use Manag. 2007, 23, 269-277. [CrossRef] 
28. Zu Schlochtern, M.P.M.; Rixen, C.; Wipf, S.; Cornelissen, J.H.C. Management, winter climate and plant-soil feedbacks on ski slopes: A synthesis. Ecol. Res. 2014, 29, 583-592. [CrossRef]

29. Burt, J.W.; Clary, J.J. Initial disturbance intensity affects recovery rates and successional divergence on abandoned ski slopes. J. Appl. Ecol. 2016, 53, 607-615. [CrossRef]

30. Pohl, M.; Alig, D.; Körner, C.; Rixen, C. Higher plant diversity enhances soil stability in disturbed alpine ecosystems. Plant Soil 2009, 324, 91-102. [CrossRef]

31. Körner, C. Alpine Plant Life Functional Plant Ecology of High Mountain Ecosystems, 2nd ed.; Springer: Berlin, Germany, 2003; p. 218, ISBN 978-3-540-65438-4.

32. Körner, C.; Spehn, E. Mountain Biodiversity: A Global Assessment; Parthenon Publishing: London, UK, 2002; p. 350, ISBN 1-84214-091-4.

33. Reubens, B.; Poesen, J.; Danjon, F.; Geudens, G.; Muys, B. The role of fine and coarse roots in shallow slope stability and soil erosion control with a focus on root system architecture: A review. Trees 2007, 21, 385-402. [CrossRef]

34. Rivella, E.; Molinari, V.M. Piste da sci. In Edilizia per L'ambiente, Progettare: Metodi, Tecniche, Norme, Realizzazioni; Socco, C., Rivella, E., Maffiotti, A., Eds.; Utet Giuridica: Milano, Italy, 2006; Volume 7, pp. 257-261. (In Italian)

35. Krautzer, B.; Wittmann, H.; Peratoner, G.; Graiss, W.; Partl, C.; Parente, G.; Venerus, S.; Rixen, C.; Streit, M. Site-Specific High Zone Restoration in the Alpine Region: The Current Technological Development; HBLFA Raumberg-Gumpenstein: Irdning, Austria, 2006; p. 30, ISBN 3-901980-96-2.

36. Spiegelberger, T.; Bassignana, M.; Madormo, F. (Eds.) Les Semences Locales Dans la Restauration Écologique en Montagne-Production et Utilisation de Mélanges pour la Preservation; Tipografia Testolin Bruno: Sarre, Italy, 2015; pp. 5-96, ISBN 978-88-906677-9-4. (In French)

37. Krautzer, B.; Graiss, W.; Peratoner, G.; Partl, C.; Venerus, S.; Klug, B. The Influence of Recultivation Technique and Seed Mixture on Erosion Stability after Restoration in Mountain Environment. Nat. Hazards 2011, 56, 547-557. [CrossRef]

38. Argenti, G.; Ferrari, L. Plant cover evolution and naturalisation of revegetated ski runs in an Apennine ski resort (Italy). iForest 2009, 2, 178-182. [CrossRef]

39. Hagen, D.; Hansen, T.-I.; Graae, B.J.; Rydgren, K. To Seed or Not to Seed in Alpine Restoration: Introduced Grass Species Outcompete rather than Facilitate Native Species. Ecol. Eng. 2014, 64, 255-261. [CrossRef]

40. Klug, B.; Markart, G.; Meier, J.; Krautzer, B.; Kohl, B. Ski Run Re-Vegetation: A Never-Ending Story of Trial and Error? In The Impacts of Skiing and Related Winter Recreational Activities on Mountain Environments; Rixen, C., Rolando, A., Eds.; Bentham Science Publishers: Bussum, The Netherlands, 2013; pp. 155-183, ISBN 978-1-60805-632-3.

41. Malaval, S.; Dupin, B.; Dantin, G. Conservation et restauration de la flore dans un contexte anthropisé, quelles solutions? Sci. Eaux Territ. 2015, 16, 70-75.

42. Alpine National Botanical Conservatory. Available online: http:/ /www.cbn-alpin.fr/index.php?option= com_content\&id=180\&lang=fr\&layout=edit\&view=article (accessed on 28 September 2017).

43. Felber, H.U.; Hirsch, M.; Walther, P. Interventi sul paesaggio a favore della pratica dello sci. In Direttive per Il Rispetto della Tutela della Natura e del Paesaggio; Federal Office for the Environment: Bern, Swizerland, 2000; p. 74. (In Italian)

44. National Ski Area Association-NSAA. Available online: www.nsaa.org (accessed on 24 August 2017).

45. Sustainable Slopes Environmental Charter. 2005. Available online: http://www.nsaa.org/environment/ sustainable-slopes / (accessed on 24 August 2017).

46. Suistanable Slopes-Annual Report. 2016. Available online: http://www.nsaa.org/environment/ sustainable-slopes / (accessed on 24 August 2017).

47. Rivera, J.; deLeon, P.; Koerber, C. Is greener whiter yet? The Sustainable Slopes program after five years. Policy Stud. J. 2006, 34, 195-221. [CrossRef]

48. Cernusca, A.; Tappeiner, U. Impianti di Risalita e Piste da sci. In Linee Guida per le Procedure di Valutazione di Impatto Ambientale. Available online: http://www.valutazioneambientale.provincia.tn.it/binary/pat_ valutazioneambientale/pubblicazioni/9.15_Impianti_di_risalita_e_piste_da_sci.1268233549.pdf (accessed on 12 September 2017). (In Italian)

49. Geneletti, D. Impact assessment of proposed ski areas: A GIS approach integrating biological, physical and landscape indicators. Environ. Impact Assess. Rev. 2008, 28, 116-130. [CrossRef] 
50. Istituto Superiore per la Protezione e la Ricerca Ambientale ISPRA. Il Trattamento dei Suoli nei Ripristini Ambientali Legati alle Infrastrutture. Available online: http:/ / www.isprambiente.gov.it/ files / manuale652010/65.2-suoli.pdf (accessed on 17 October 2017).

51. Istituto Superiore per la Protezione e la Ricerca Ambientale ISPRA. Linee Guida per la Valutazione del Dissesto Idrogeologico e la sua Mitigazione Attraverso Misure e Interventi in Campo Agricolo e Forestale. Available online: http:/ / www.isprambiente.gov.it/files/pubblicazioni/manuali-lineeguida/MLG_85_2013. pdf (accessed on 17 October 2017).

52. Locher Oberholzer, N.; Streit, M.; Frei, M.; Andrey, C.; Blaser, R.; Meyer, J.; Muller, U.; Reidy, B.; Rixen, C.; Schutz, M.; et al. Linee Guida per Il Rinverdimento ad Alta Quota; AGHB Bollettino ${ }^{\circ}$ 2, Luglio; Verein für Ingenieurbiologie: Wädenswil, Switzerland, 2008; p. 35. (In Italian)

53. Zanini, E.; Romeo, R. Introduction. In Understanding Mountain Soils: A Contribution from Mountain Areas to the International Year of Soils 2015; Romeo, R., Vita, A., Manuelli, S., Zanini, E., Freppaz, M., Stanchi, S., Eds.; FAO: Rome, Italy, 2015; pp. 8-9, ISBN 978-92-5-108804-3.

(C) 2017 by the authors. Licensee MDPI, Basel, Switzerland. This article is an open access article distributed under the terms and conditions of the Creative Commons Attribution (CC BY) license (http:/ / creativecommons.org/licenses/by/4.0/). 